\title{
Hybrid methodology of multi-sensory research of public space in urban planning
}

\author{
Ewa Jarecka-Bidzińska \\ Faculty of Geodesy and Cartography; Warsaw University of Technology; \\ 1 Politechniki Sq., 00-661 Warsaw, Poland; \\ ewa.bidzinska@pw.edu.pl (D)0000-0002-1289-9784
}

Financing: The research was co-financed by the Dean's Grant at the Faculty of Geodesy and Cartography of the Warsaw University of Technology obtained in 2018, No. 504/04093/1060 / 42.000100, entitled "The importance of identity in shaping selected new urban spaces in Warsaw's Praga - Północ district”.

Abstract: The concept of multi-sensory perception of cities is one of the elements shaping the complete image of the city. It is an aspect as important to the recipient as the urban structure. The study of the multisensory record of public spaces gives a better chance to understand: the identity of the place, the changing dimensions of cultural heritage, local social problems, and even conditions influencing spatial decisions. Multisensory research has an implementation value and can be an important, previously unaccounted for factor, influencing the revitalization program and planning decisions. Therefore, it is so important to analyze the available literature on the subject, conduct scientific observation of the research area, create a proposal for a hybrid research methodology on multi-sensory recording of space and determine their relationship with activities in the field of urban planning. The trial area - selected public spaces of the Praga - Północ district in Warsaw was adopted according to predetermined criteria, the most important of which were: authentic urban tissue, downtown area, architectural and functional diversity of buildings.

Keywords: multisensory research, multisensory space, public space, Praga - Północ

\section{Introduction}

\subsection{Justification and purpose of the undertaken research}

The city is a multi-spatial work, the perception of which is based on multi-sensory perception. The study of multisensory recording of space allows to obtain information on multisensory perception, valorization and their relation to space also as part of in situ assessment. This is important for holistic assessment of the quality of public spaces, their potential 
and cultural heritage. This knowledge allows for fully conscious organization and transformation of public spaces. It has an implementation value and may constitute an important factor, previously not taken into account in urban planning, influencing the revitalization program and planning decisions. This is the basis for constructing an assessment and conclusions regarding the transformation of public spaces, taking into account its invisible dimensions. The essence of multi-sensory research is defined sociologically by B. Jałowiecki - contemporary interest in research on the perception of space has become important due to the degradation of the natural environment [of the city - ed. author] and the living conditions of inhabitants of large cities deteriorating despite the development of civilization [1]. Problems such as, for example: destruction of historical buildings, poor technical condition of residential buildings, developer pressure, lack of green areas, recreation and rest, long journeys to work, uniform architecture, spatial disorder or lack of basic services affect the multi-sensory perception of public spaces. These problems worsen the health of the inhabitants and, consequently, lead to pathologies, acts of vandalism, affect social migrations, suburbanization and urban sprawl.

The aim of the work was, after analyzing the existing data and conducting scientific observations and reviewing the literature on the subject, to create a proposal for a hybrid methodology of multisensory research in public spaces and verify it on a trial group of respondents, and to present urban design suggestions based on the conducted hybrid multisensory research. The proposed research methodology may turn out to be useful in urban planning activities, serve to construct a multi-sensory record of space and urban design suggestions. An attempt was made to describe the reasons for the obtained initial multi-sensory assessment of public spaces. A trial study of the proposed methodology confirmed the possibility of its wider application in other areas and revealed the differences between the recording and sensory valorization of space in the context of various senses. Some spaces, assessed positively in terms of visuals, received a low score in terms of the sense of hearing or smell, which affects the overall multi-sensory image and constitutes the legitimacy of taking up the title methodology. The article ends with considerations on finding design solutions that take into account the multi-sensory record of space and favor the improvement of the current situation. The legitimacy of research is also based on the activity to support innovative development strategies related to the cooperation agreement between the Capital City of Warsaw, the Praga-Północ District Office, and the Department Geodesy and Cartography of the Warsaw University of Technology.

\section{Analysis and review of literature}

The senses were first described by the Greek philosopher Aristotle around 350 BCE. distinguishing five senses: sight, hearing, smell, taste and touch [2]. According to the Mały Słownik Psychologiczny [3], the concept of sense is "sensitivity, the ability to perceive a specific category of stimuli in the form of impressions". The number of senses includes sense of sight, hearing, smell, taste, touch, temperature, kinesthetic, balance, joint and muscular, cenesthetic, pain. It definitely exceeds the colloquial five mentioned as the number of human senses. According to Słownik Psychologii [4] sense is "each of the faculties by which one can experience the outside world or the internal states of one's own organism."

The sensual record of public space was initiated with the publication of "The Image of the City" in the 1950s, where the American urban planner and writer Kevin Lynch created the memory-related visual sense method of mental maps in city studies. The theory of research on the multisensory perception of public spaces was later developed in many disciplines: environmental psychology, sociology, geography, cartography, ethnography, urban anthropology, cultural studies, geographic information systems and psychocartography. The K. Lynch 
collective map is the most common and cited - the quantitative signature method involving the counting of objects. He created a method that was effective in research on the urban landscape and urban composition, in which sketchy cognitive maps were used. The elements presented in them were counted and assigned in 5 categories: paths, borders, nodes, landmarks and regions, and compared with the frequency of indications. According to Lynch, the title "image of the city" is based on social relations and staying in given spaces, and depends on the sensitivity of the senses. However, this method applies mainly to the sense of sight, and freehand sketches made by the respondents are drawn outside the area covered by the study and contain distortions of distance or direction. As part of this method, the respondent does not specify the assessment, but only a distorted drawing of the projection of a part of the city with the marking of points that are the material in the quantitative method. The answer to the search for a method of sensual study of space with the character of valorization is the research of another architect and urban planner - K. Wejchert. He created a qualitative method covering the meanings and assessments of sensations, a graphic representation of the record of these sensations and the perception of urban spaces [6], [7]. He also developed a methodology of research and valorization, useful in urban planning, showing the aesthetic value of urban spaces using a graph known as the "Wejchert impression curve". This study, covering only the sense of sight, inspired the development of the title methodology to include other senses as well.

Previous research in the disciplines of sociology and environmental psychology was aimed at examining the mechanism of perception, mapping real space and determining the impact of perception on society. The problems of the city in the experiences of individuals and communities as well as human behavior in the urban environment were studied. In Poland, the precursors of research on the perception of the environment and cognitive maps of the environment were, under the supervision of T. Tomaszewski [8], [9] - M. Susłowska and M. Sawicka in Kraków, and A. Eliasz, K. Skarżyńska and T. Szustrow in Warsaw. The development of the theory of cognitive maps was investigated by A. Hauziński in the publication "Evolution of the concept of a cognitive map in psychology. Review of research on the hierarchy of plans and action goals" [10]. It distinguishes several types of cognitive maps, including: image of oneself, the closest surroundings, a diagram of the environment, a map of the world, a map of the universe and a worldview - representation of the real world. In his opinion, cognitive maps are used to acquire, use and formulate assumptions based on knowledge about oneself, the spatial and social environment and one's orientation in it. However, in the publication "The evolution of the concept of a cognitive map in psychology and its use in urban planning, architecture and geography" [11] he describes disciplines outside of psychology in which cognitive maps are used, inter alia, urban planning, architecture and geography. Environmental psychology issues have also been included in numerous publications by R.G. Golledge "Methods and methodological issues in environmental cognition research" [12], GW Evans "Cognitive mapping: Knowledge of real-world distance and location information" [13], "Environmental cognition" [14], "Environmental learning and cognitive mapping. Environment and Behavior” [15], “The effects of pathway configuration, landmarks and stress on environmental cognition. Journal of Environmental Psychology" [16] or J. E. Foley“ Working mental representations of the environment. Environment and Behavior” [17]. J. O’Keefe, J., Nadel, L. in "The hippocampus as a cognitive map" [18] proposed two types of thematic and topographic cognitive maps, and in the structure of the image of spatial knowledge they proposed two basic categories of road and maps. The research on the relationship between environmental psychology and architecture is described by: A. Bańka, among others, in the publications "Architecture of the psychological space of life. Behavioral foundations of design." [19] and 
"Social environmental psychology" [20]. It determines that everything that is covered by human senses or images must exist in real or mental space. It presents architectural and urban spatial problems, their causes and recommendations for design based on psychological knowledge. Numerous observations turned out to be also important in the title article due to the reference to many senses in space and the explanation of problems and proposals for spatial solutions related to it. However, it does not address the question of the methodology of researching these senses in space, and the conclusions are a set of general knowledge about implementation values. The publication "Environmental Psychology" [21] P.A. Bell, T.C. Greene, J.D. Fisher and A. Baum defines that the term cognitive maps has a different meaning and that the term "cognitive collage" is appropriate.

The issues of using the senses in the perception of the surrounding space in the sociological aspect were described, among others, by B. Jałowiecki in "Perception of the space of Warsaw" [22] and B. Jałowiecki and M.S. Szczepański in the publication "City and space in a sociological perspective" [1]. The chapter devoted to the sociological concept of space is descriptive and emphasizes the importance of perception and valorization of urban spaces. However, it does not contain a proposal of a research methodology on the multisensory study of space. The cultural and psychological aspects of urban anthropology in the perception of space have been described in the publications of E. Szkurłat "Psychological and cultural determinants of the perception of the environment" [23] and "Beyond writing / reading the city" by E. Rybicka [24]. Another researcher, Ewa Rewers, stated: "I wrote about cities that I not only saw and met, but also experienced in the practical effort of my mind and the kinetic experience of the body. It is rather a record of multidirectional, but not chaotic movement, than forcing urbanity into a ready-made network of concepts and terms " [25]. Nevertheless, in the field of social sciences, the research of B. Kietlińska in the article entitled "Research on the sensual perception of the city using qualitative methods" is the closest to the subject of the title [26]. Georg Simmel devoted his text "Sociology of the Senses" to the subject of the senses in society [27]. Sarah Pink described sensory ethnography in the publication "Doing sensory ethnography" [28]. These are sociological, ethnographic and descriptive research. These studies do not contain a deformation-free graphic record of multisensory research or reference to functional, spatial and compositional aspects. They are used to analyze the phenomenon of perception and it is not important to place them in a specific space.

The issues of social geography in terms of the perception of space, urban planning and planning based on the ideas contained in mental maps were included in the publication by M. Bartnicka "Wyobrażenia Miejskiej Warszawy" [29]. This is shaped by the trend of the geography of perception developed by other researchers, H. Libura [30] and S. Mordwa [31], who undertake the problem of comparing spatial images of different cities. Standardized Esthetic Landscape Estimation - SBE - Scenic Beauty Estimation was created and published by Daniel T.C., Boster R.S. in "Measuring Landscape Esthetics: The Scenic Beauty Estimation Method" [32]. Further research in this area was performed by M.A. Okołowicz and J.M. Kowalska in the publication "What kind of nature do we want in cities? Measurement of the aesthetics of the landscape on the Vistula River in Warsaw using the Scenic Beauty Estimation method" [33]. The riverside areas located in the central part of the city were examined in terms of spatial order by analyzing the visual assessment of the inhabitants. The study area was divided into elements of spatial composition: forest, path, shore, beaches, bridges, playgrounds and boulevard. The respondents assessed individual places on the basis of photos solely. Thus, they may not even have had experiences with them. Nonetheless, the aim of the title article is to create 
a methodology of research carried out in situ - in place, by people who know a given space, e.g. residents, employees or students.

Research on the border of psychology and cartography can be divided into two trends: structural and evaluative mapping. Structural mapping derived from the research of K. Lynch was developed by R. Kitchin in numerous publications, including: "Cognitive maps: what are they and why study them?" [34], "Methodological convergence in cognitive mapping research: Investigating configurational knowledge" [35], or "The cognition of geographic space" [36]. He introduced two-dimensional regressions and pointers to reduce the sum of position errors. Sonia Maria Vanzella Castellar and Paula Cristiane Strina Juliasz in the publication "Mental map and spatial thinking" [37] describe the issues of relations of mental maps and their reference to the real space of cartography. The publication of S. Waterman and D. Gordon "A quantitative-comparative approach to analysis of distortion in mental maps" [38] presents a quantitative procedure for the analysis and comparison of distortions in mental maps. In studies of cognitive maps in the structural trend, the interpretation of the results of sketch maps is hindered by differences in style, scale and detail. However, information is provided on the significance of selected spatial objects in the study area for the social community. Another trend of research on cognitive maps is evaluative mapping, the precursor of which was P. Gould, which he described in the publication "On mental maps" [39]. He examined the valuation of fragments of space by a certain community. These studies were further developed - H. Libura in "Some Cartographic Aspects of Imaginary Maps" [30]. Information is obtained using the choropleth method by ranking areas or marking areas by the respondent on the prepared maps. Evaluative mapping, although associated with the mechanisms of stereotyping, is important in planning and spatial decisions.

Research in the field of psychocartography by A. Gendźwiłł [40], A. Foland in "Psychokartography - a method of studying urban space" [41], or M. Lewicka [42] usually present a broader, more general and developed in larger areas cartographic image of the valorization of areas. Unlike Gould maps, they are not limited to the administrative boundaries of areas. However, imaging the "psychological properties of space" on a city scale does not allow for a detailed assessment of, for example, a single street or building, which is obtained by combining various methods carried out on the spot: interview, valorization and questionnaire. This problem is described by B. Iwańczak in "Research methods for the overall perception of city space on the example of Warsaw" [43], who at the outset proposes functionally and spatially coherent research areas of the city using GIS tools. The issues of using the geodetic and cartographic information system as well as the presentation of mental maps are also described by K. Nieścioruk in the publications "Cartographic image of mental maps of urban space and its presentation and analysis with the use of geographic information systems" [44], "The use of mental and sketch maps as a tool to evaluate cartography teaching effectiveness "[45]. These studies became an inspiration to include in the title methodology of research multi-sensory functional and spatial analyzes of the area performed in a traditional way and preceding the next stages of the research process. So far, research in the field of psychocartography has not covered multi-sensory studies of spaces, but only, for example, the assessment of attractiveness or a sense of security performed outside the place subject to assessment. The location of the valorization not in real time and in isolation from the studied area allows only the memory of the senses to be used. Therefore, it would not be applicable in this case.

Interactive tools are used more and more often in the study of public spaces: geo-questionnaires, computer programs, mobile applications, virtual reality [46]-[48]. However, these methods were not taken into account when constructing the title research methodology due 
to the target lack of possibility to include digitally excluded people (the poor, the elderly, the uneducated) and the negative impact of electronic devices, such as smartphones or tablets, on the actual perception of space, or even its limitation. Development of the title methodology in the future would make it possible to introduce, depending on the preparation of the respondent, traditional questionnaires and geo-questionnaires and to compare the results.

However, the concept and definition of "public space" have been precisely defined in the Charter of Public Spaces [49], "as a common good, deliberately shaped by man, in accordance with social principles and values - serving to meet the needs of local and supra-local communities". On the other hand, The Act on Spatial Planning and Development [50] contains the following entry: "An area of particular importance for meeting the needs of residents, improving their quality of life and conducive to establishing social contacts due to its location and functional and spatial features, specified in the study of the conditions and directions of spatial development of the borough."

The current state of research does not include literature that focuses on linking the content of multi-sensory field research and the functional and spatial characteristics of places. So far, in Poland, no publication has appeared devoted solely to multi-sensory research in public space and its relationship with urban design.

\section{Research procedure in hybrid research methodology - basic theoretical assumptions}

So far, the research methodologies used and described in the literature are limited to one or two research techniques. Some of them are descriptive and concern only purely psychological issues related to the phenomenon and mechanism of perception. Some analyze representations of reality deformed by the respondents, but made outside the research site. Others relate only to the sense of sight or the assessment of attractiveness. Currently, no methodology has been developed that would lead to direct use in urban planning activities, the process of shaping and transforming public spaces. Therefore, an innovative solution was proposed that combines various research methods and presents a hybrid methodology covering at various stages: literature and data analysis, photo documentation of the areas covered by the study, in situ observation, functional and spatial analysis, discussions with experts and interviews, a scientific walk, a questionnaire and valorization of space. This allows, among others, to study multi-sensory perception while actually being in space.

The conducted research procedure (Fig. 1) consists essentially of several stages remaining in a hierarchical or more complex relationship, as presented in the diagram. The empirical part of the hybrid test method was conducted in the field. In large cities, the number of potential research points - public spaces, and the distances between them and their size are significant. The researcher's financial and time constraints do not allow for a detailed examination of everyone. Therefore, it is necessary to delimit the area and the number of points on the basis of the previously adopted criteria. The site selection process followed is complex and has several steps. It was necessary to carry out such a classification based on the analysis of aerial and satellite photos, archival plans and maps, publications and planning documents concerning the studied area. Some of the components of this procedure do not concern the subject of the article, and therefore have not been discussed in more detail. Arbitrary selection of the site influences the efficient conduct of research in the field and limits the impact of the respondent's abilities and context on the results. The research is limited by the physical condition and time disposition of the respondents (route length). Imposing on the respondents both the area and points selected for sample surveys also allowed for focusing the assessment of all respondents in pre-adopted places and the subsequent aggregation of the obtained data. 


\section{RESEARCH PROCEDURE IN HYBRID RESEARCH METHODOLOGY}

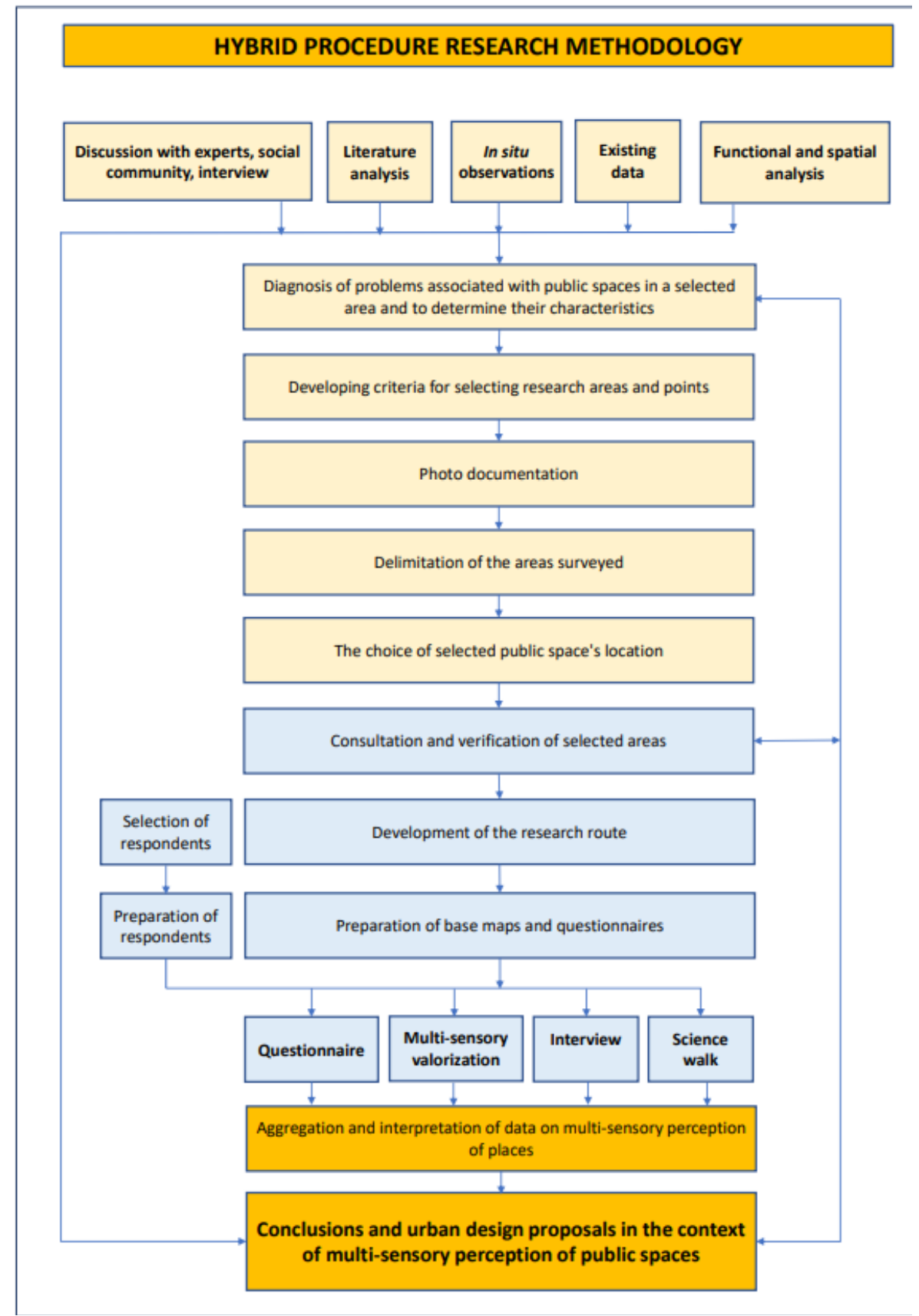

Fig. 1. Diagram of the test procedure. Source: own study 


\section{Basic criteria for selecting the area and research points}

The area and test points should be the same for all groups participating in the study. They are proposed by the person who conducts the study on the basis of the results of the previously conducted delimitation based on the established selection criteria. However, you can define the initial criteria for selecting the area and research points:

- authentic urban fabric (historic building structure and street network, preserved squares and other elements of the urban structure)

- downtown area with multi-family housing and inhabited by the local community

- presence of public utility buildings of local and supra-local importance

- partially degraded area,

- area covered by the revitalization program or planned for revitalization

- architectural and functional diversity

- the location of subsequent public spaces at a distance of no more than $500 \mathrm{~m}$ from each other (maintains the level of attention of the recipient, and at the same time allows for a smooth interpenetration of multi-sensory experiences)

- a minimum of 10 , but not more than 15 , public spaces within the route, including those of different nature and functions (streets, squares, marketplaces), too little space does not give a representative research area, and too much space requires more than 2 hours for carrying out research and is at risk of obtaining superficial and random multisensory assessment, and the obtained results would be unreliable

- attractiveness in terms of tourism, the presence of unique elements in the city scale described in the theory of K. Lynch (outstanding architecture, historical urban layout, landscape and natural values, but also social significance - e.g. memorial sites, important for the local community)

- linking the paths with the pedestrian function - a common trail

When using this methodology in another area, it is allowed to slightly modify the criteria, e.g. in small areas or on the outskirts of large cities. The route, the image of which on the map allows you to create a circumference of a closed figure, allowing for a cyclical scientific walk, and at the same time delimiting an area which, together with a buffer zone of at least $1 \mathrm{~km}$, may constitute an intermediate zone of influence on the senses (heard sounds, visible architectural dominants). Such a route allows for re-examining and reading the senses in the public space after the expiry of the time allocated for one cycle. The study covered a trial area of the Warsaw district of Warsaw - Praga - Północ, as it met the set criteria.

\section{The area of trial hybrid multi-sensory research of public space in urban planning}

The scope of the research procedure included the most important public spaces of Praga - Północ on a continuous route, including: Różycki Bazaar, Ząbkowska Street, Targowa Street, Wileński Square, Weteranów Squarr 1863, Floriańska Street, but also commercial places such as Koneser Square. The reasons for choosing these particular parts of the district were: the historical significance of the area, the concentration of services and trade, and the associated greatest social, as well as cultural and tourist popularity. The dynamics of functional and spatial changes, but also social and economic changes, were important. The area of Praga - Północ selected for research is the only area in Warsaw where the process of spatial transformations of 
the city in the $19^{\text {th }}-20^{\text {th }}$ centuries is visible in the urban tissue, mainly industry. The left-bank development of Warsaw was demolished in $85 \%$ during World War II, Praga - Północ only in $25 \%$, therein mainly industry. This area also presents Christian, Jewish and Orthodox cultural and religious heritage. It is an area containing, among others, fragment of the UNESCO buffer zone, areas included in the register of monuments and in the municipal register.

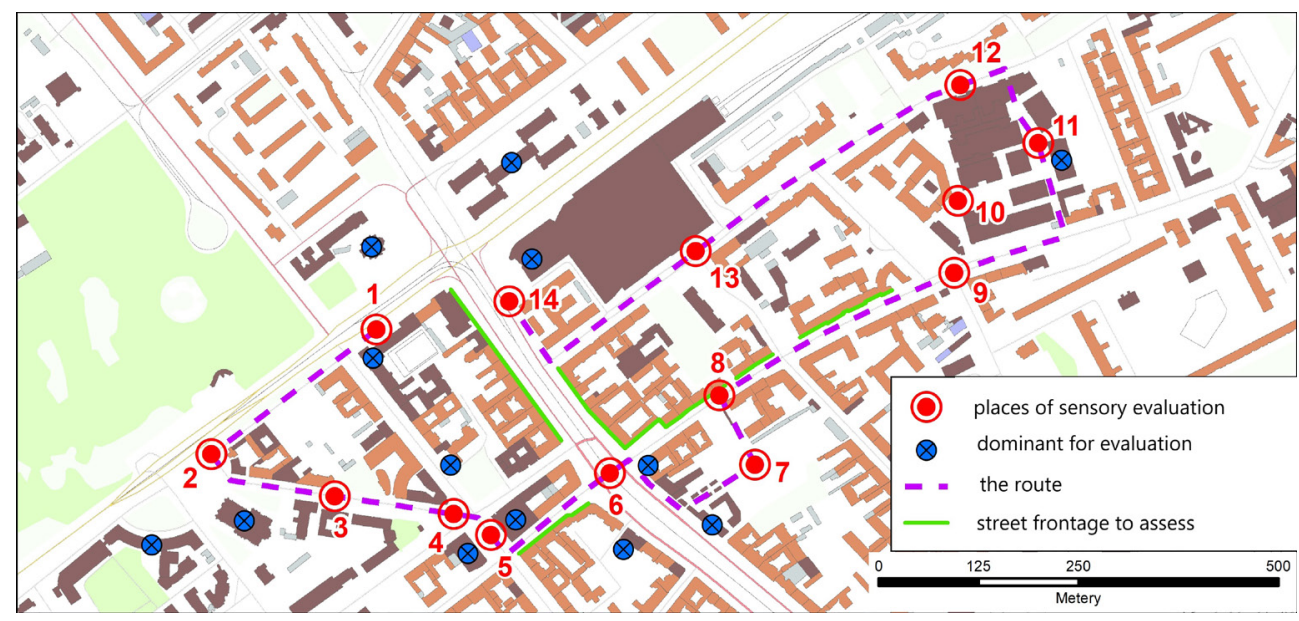

Fig. 2. The route of the field study on the creation of mental maps of public spaces, October 2019, source: author of the graphic presentation of the map, M.Sc.Eng. M. Delnicki on the basis of research by the author. Public spaces: 1 - near Władysława IV High School, 2 - Veterans Square in 1863, 3 4 Floriańska St, 4 - square at Praska Kapela, 5 - square at the Tax Office, 6 - intersection of Targowa St. and Jagiellońska St., 7 - Różycki Bazaar, 8 -Ząbkowska St., 9 - intersection of Ząbkowska St. and Markowska St., 10 - entrance to the Koneser Praga Center, 11 - Koneser Square, 12 - Białostocka St., 13 - corner of Brzeska and Białostocka streets, entrance to the shopping center, 14 - Dworzec Wileński entrance zone

The route starts near Wileński Square (Fig. 2, no. 1), which is currently the largest communication junction (15 thousand 176 to 31 thousand 628 passengers a day) [52] and the most recognizable place in the district. This intersection of multi-lane roads is located next to the Vilnius Railway Station (Fig. 2, no. 14), and at the location of the metro station. Together with the development and domination of the communication function, this square no longer meets other social needs. It is rarely chosen by individual users for recreational or interpersonal integration purposes, and these functions are performed by users in the shopping center located above the Vilnius Railway Station. Then, the route leads through Veterans Square of 1863. (Fig. 2, no. 2), an important element of the local spatial order and a historical fragment of the urban layout associated with the Royal Castle from the times of Tsar Alexander II. according to a design by J. Kubicki. It is definitely one of the most recognizable places in the district, mainly due to the Praga Hospital operating in the historic buildings and the landscape dominant visible from the left bank of Warsaw, which is the Cathedral of St. Florian the Martyr and Michael the Archangel. The route continues along one of the most charming streets of Praga - Północ - along Floriańska Street (Fig. 2, no. 3; Fig. 5), where the modern architecture blends harmoniously with the historic buildings, and the spatial order is complemented by rows of trees, creepers growing on the walls and urban details such as lanterns type of the Warsaw crosier, authentic pavement, or the famous Monument to the Praga Backyard Band. 
The route continues through the space between the Tax Office, the Warsaw-Praga Curia, and the Marshal's Office (Fig. 2, no. 4-5; Fig. 5), which, despite its potential, currently serves as a car park. Subsequently, the research was carried out along the frontage of historical buildings at Okrzei St., which together with Ząbkowska Street, commonly known as the "Praga New World", is a part of the Praga Princely Route. Next, the route of the research leads through Targowa Street (Fig. 2, no. 6; Fig. 4), which in the urban structure also includes the preserved elements of the medieval street layout related to the original physiographic conditions of the area and a spindle-shaped commercial settlement. The former large market, which was a city-forming element, was transformed into the settlement of Targowe Wielkie in the $14^{\text {th }}$ century, which gave its name to the most important street in Praga. Then, the route leads to the adjacent Różycki Bazaar, built in 1901, which used to be the "functional heart of Praga". Currently, less popular, although it still has a commercial function and due to its importance for local heritage, it is revitalized (Fig. 2, no. 7; Fig. 6). The course of the route returns to Ząbkowska Street (Fig. 2, no. 8-9; Fig. 4) and then into Praga's Koneser Center Square (Fig. 2, no.10-11; Fig. 3) - a commercial multi-functional public space constituting a juxtaposition of contemporary facilities and adapted to new historical functions of the former Koneser Vodka Factory. Due to the supra-local functional and spatial attractiveness, historic, unique buildings, aesthetics, and cultural aspects, the space is focused on tourism and social life. Next, the route runs through the opposite exit from Koneser Square along Białostocka St. (Fig. 2, no. 12-13; Fig. 3) passes the 1980s multi-family housing development by the railway line and ends at the square in front of the Vilnius Railway Station (Fig. 2, no. 14)
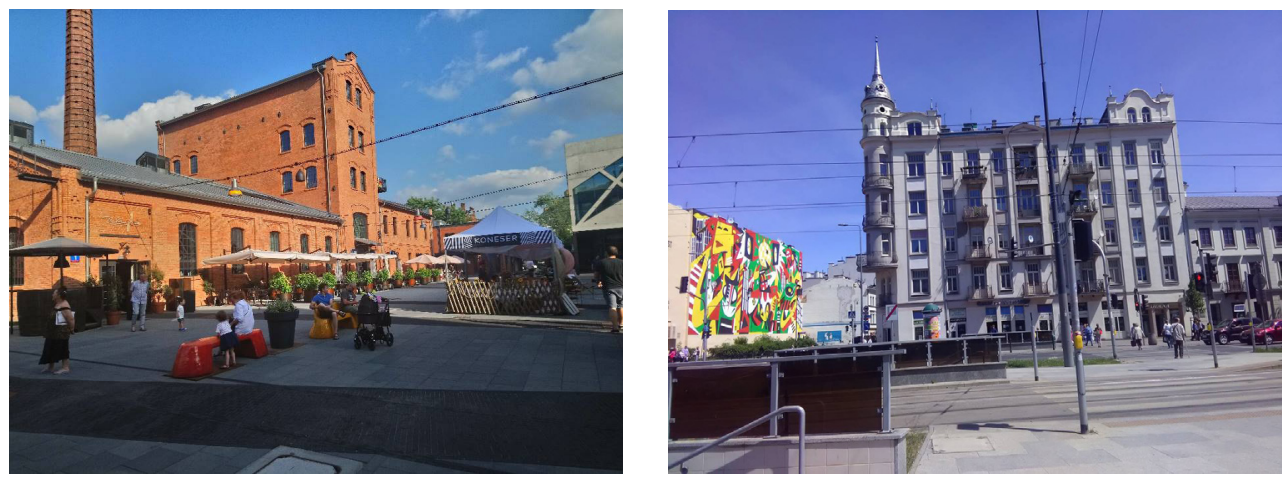

Fig. 3. Koneser Square, October 2019, Source: Fig. 4. author's own archive Targowa Streets, 2016, Source: author's own archive

\section{Hybrid multi-sensory research of public space in a trial area - case study}

The area of trial research was selected on the basis of the criteria adopted previously and discussed in the preceding chapter, the most important of which are: authentic urban tissue and architectural and functional diversity of buildings. 14 unique research areas were distinguished, and each of them was assigned 1 point. They are located in close proximity and allow you to create a pedestrian route - a closed-circuit route. In order to minimize subjective classification, the methodology uses in the initial stages of the research: functional and spatial 
analysis, observation of the terrain in situ and discussion with experts. Photographs were taken at the designated research points and observation protocols were prepared.

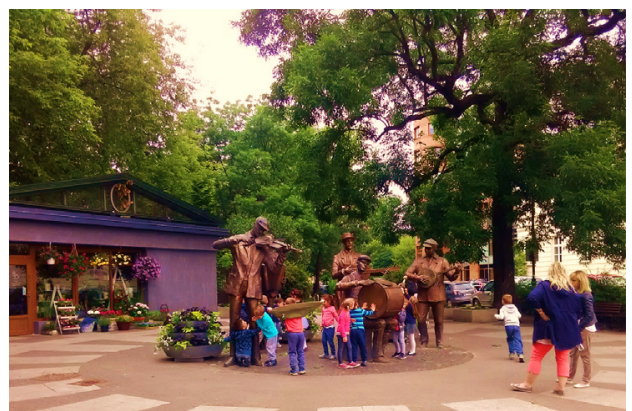

Fig. 5. Square at the intersection of Floriańska and Kłopotowskiego Streets, visible sculpture and children interested in it, May 2016, Source: author's own archive

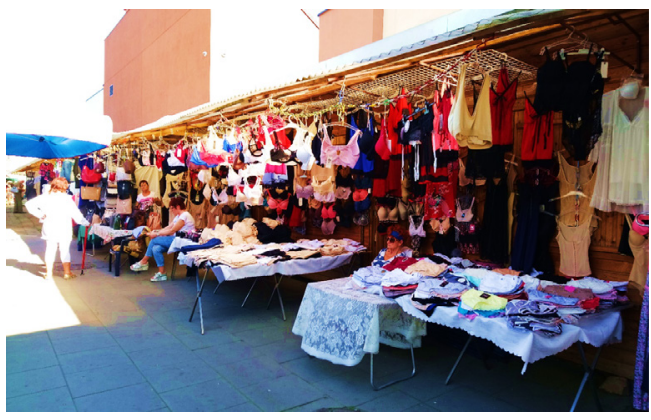

Fig. 6. Różycki Bazaar, 12:00 p.m, visible variety of colors at the stalls, October 2018, Source: author's own archive

The preparatory stage consisted in setting out, according to the established criteria and after delimiting the areas by the author, the research route, places for reading multi-sensory experiences, as well as dominants and frontages to be assessed. The route and test points (dashed purple line, Fig. 2) were selected in such a way as to objectively present the complex nature of Praga - Północ. The route covered the most important public spaces of the functional center of Praga - Północ. It started at the school building Władysława IV VIII High School at the intersection of Jagiellońska Street and Solidarności Avenue, and then historical areas dominated by monuments (Floriańska St., Fig. 5; Ząbkowska St., Fig. 4), very degraded areas of great social importance (Bazar Różyckiego, Fig. 6), large communication arteries (Targowa St., Fig. 4), areas of a commercial character and high aesthetic value (Centrum Praskie Koneser, Fig. 3). The examination lasted approximately 2 hours and proceeded at a pace adjusted to the needs of the group, so that the multi-sensory assessment of the site could be carried out on an individual basis. The study area (Fig. 2) was divided into sections, the most important point of which was the selected public space with an assigned number and name in the table. For many years, the author conducted research in the area of Praga - Północ and was based on the results of the doctoral dissertation entitled "Praga - Północ in Warsaw as an" art district "against the background of selected examples from the metropolises of Europe and North America" [51]. During the site visits carried out many times from 2016 to 2019, a total of over 150 photos were taken, 10 for each public space. The photos were taken from the observer's level and from viewpoints. The acquired knowledge and conclusions from previous consultations with the local government, including the Head of the European Funds Department in the PragaPółnoc District Office, became the basis for choosing the route on which the assessment was made as representative of the district.

As part of the study, in the last phase, questionnaires, multi-sensory valorization on base maps, an interview and a scientific walk were performed. The following senses were selected for the study: sight, touch, taste, smell, hearing, time perception and proprioception. The technique allowed for scoring according to individual senses in the questionnaire in the form of a table on the assessment of the place in terms of the specified senses and on the map in the form of graphic symbols, as an evaluation. In addition, it made it possible to place 
other information that was also the equivalent of free interview, including those related to the assessment of spatial order or subjective experiences in precise definition. The assessment in the questionnaire was three-level and presented in a table in the window corresponding to specific senses. Table - the questionnaire related to specific places on the map. The spaces were scored with points from -1 to 1 . The rating scale was $(-1,0,1)$, where -1 means negative, 0 - neutral, and 1 - positive. The sum of points obtained in the assessment for a given place is presented in the figure below in the charts. The participants of the study made an assessments of all the places previously selected by the author without any exception.

In addition to the scoring of public spaces in the questionnaire, graphic studies were also prepared - multi-sensory valorizations with detailed information and handwritten on the printed map with the use of sticky circle markers (of different colors depending on the assessment) of arrows, colored lines symbolizing various information, markers, felt-tip pens and post-it notes (Fig. 7). The individual graphic elements applied by the participants of the study had the meaning assigned in the legend, e.g. attractive and unattractive space, negative and positive dominants, socially important place, directions of population movement, valuable greenery and tree stand, etc. It was also a rich study in terms of presenting subtle feelings. This method also uses, among others, the assessment of areas by the respondents. Attractiveness or social significance, and a dichotomous scale (attractive/unattractive space, dominant) was adopted for the respondents' points as well. The aggregation and processing of these data was based on the research by A. Foland [41] and B. Iwańczak [43] in a simplified version - allowing for the formulation of project conclusions and confirmation of the effectiveness of the developed methodology. The respondents, using appropriate markings, assessed the following described and categorized by K. Lynch: [5] knots, regions, landmarks - waypoints and selected edges and bands with an assessment. This allows you to determine the importance of individual elements in space. Table 1 presents the definition, identification and recording of descriptive data formulated by the respondents. 


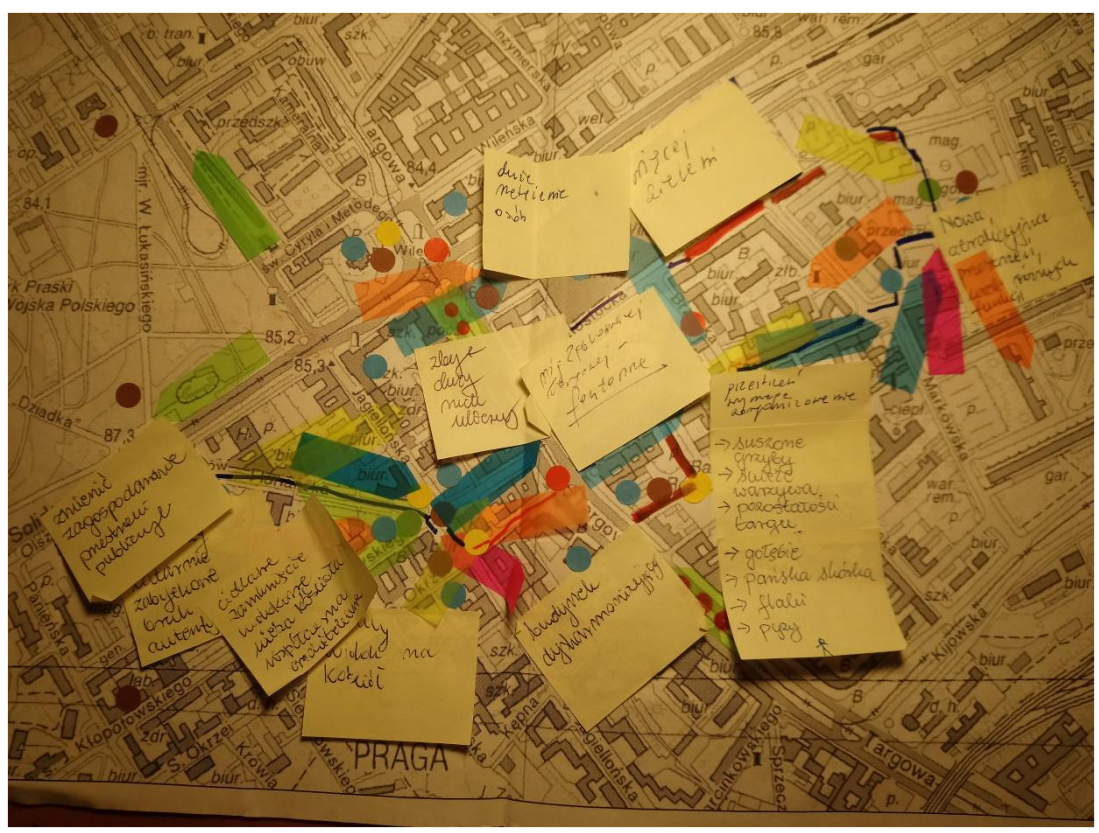

Fig. 7. Sample multi-sensory valorization - one of the many graphic studies created during the field research, which are part of the hybrid research methodology, made by residents participating in the workshops based on the graphic legend prepared by the author and additional records of impressions presented according to their own graphic interpretation, November 2019, Source: own study

As an observer, the author accompanied the respondents in the study, conducted a free group interview and noted their sensory reactions described in words and gestures during the research walk. They were assigned to individual research points. The interviews and research notes were coded in a descriptive manner in accordance with the principles of conducting interviews, as presented in the table below. A method of coding the so-called a priori coding (concept driven coding), focused on finding traces in the previously transcribed data referring to previously adopted concepts or constructed on the basis of other research methods of conclusions (Table 1). In the case of this method, the subject of interest was everything that accompanies multisensory perception in the functional and spatial aspect, i.e. the behavior and actions of respondents in relation to the environment, events, feelings and emotions, states, conditions (both atmospheric and related to natural and anthropogenic), limitations and barriers, respondents' attitude to space, their attitude and expectations, relations and interactions between the social community and changes and processes in public space noticed by respondents. 
Table 1. Example of a coding fragment for multi-sensory perception interviews. Source: own study

\begin{tabular}{|c|c|}
\hline Text & Descriptive code \\
\hline $\begin{array}{l}\text {,there are many services here and everyone will find something for } \\
\text { themselves "," a beautiful place, I'll be happy to come back in here } \\
\text { "," how good that there are no cars here "," this environment is } \\
\text { inspiring "," you can spend time here" }\end{array}$ & Freedom of action in space \\
\hline $\begin{array}{l}\text { "it stinks, you can't breathe "," you can 't hear anything, you have to } \\
\text { go away from here "," those old and dirty yards are terrible, damp } \\
\text { and musty everywhere "," it smells like construction site and dust is } \\
\text { everywhere" }\end{array}$ & Irritation, excess stimuli, stressors \\
\hline $\begin{array}{l}\text { ", "you can see the church tower from afar "," this school is right at } \\
\text { the crossroads "," you can see the church from here "," the entrance } \\
\text { gate to the courtyard can be seen from a distance "," everyone goes } \\
\text { one way in the morning and the other in the evening ", }\end{array}$ & Proper orientation in space \\
\hline $\begin{array}{l}\text { ", nice place and a lot of people "," you can hear nice music in the } \\
\text { cafe garden "," there are always a lot of people here "," smells beau- } \\
\text { tifully with donuts "," wonderful smell of dinner", }\end{array}$ & Living space \\
\hline $\begin{array}{l}\text { "empty, no people “,” smells of old age “,” It's boring in here, noth- } \\
\text { ing is happening ", }\end{array}$ & A socially dead space \\
\hline $\begin{array}{l}\text { ",this street is nice with trees and greenery, you can stay here longer } \\
\text { "," this is my favorite street because it's so quiet, green and pretty" }\end{array}$ & Positive value of urban greenery \\
\hline $\begin{array}{l}\text { "this is a special place, because I like these people and this building } \\
\text { "," it is a very fashionable place now, even tourists come here "," this } \\
\text { is the most popular street "," epic place" }\end{array}$ & The identity of the place \\
\hline $\begin{array}{l}\text { "this is the largest intersection, I drive this way every day, there is } \\
\text { always a lot of people "," here, it is close to everything, close to } \\
\text { services, to the center" }\end{array}$ & Understandable space \\
\hline
\end{tabular}

As part of the accepted research, the penultimate phase of research, was carried out on various groups of respondents. The first research procedure in October 2019 involved 5 teams of subjects of the same age but of different sex, included 35 people. Each group consisted of 5-7 people who were students of a secondary school located in the center of the study area. ${ }^{l}$ Most of the respondents were residents or everyday users of the studied areas of right-hand Warsaw, i.e. the studied area or its vicinity. The group of respondents was selected on purpose - as a trial group. They were the students of Władysław IV, VIII High School in Warsaw, which is located in the studied area. It can therefore be assumed that these are people who meet the requirements described by environmental psychology in the previously discussed sections, including A. Bańka [19] The respondents knew the studied spaces through the prism of personal experiences and everyday social interactions. They efficiently and consciously moved around the studied area and were able to work as a team on the development of the valuation and the questionnaire. Children are also the social group which, quoting S. Mordwa [31] most willingly makes graphic studies or a graphic presentation of ideas of space. This group of respondents favored the achievement of the goal - efficient conduct of the survey, and thus checking the entire innovative methodology. It is possible to perform the title methodology on another community as well. In such research, it is also important to properly prepare the respondents (A. Hauziński) [10] [11]. Therefore, the field research was preceded by classroom activities presenting the theory of the research and explaining the goals and method of execution.

1 The second study took place in November 2019. with the participation of a small group of municipal authorities and residents. It has not been described in greater detail due to the slight influence on the results of the research. 
Later, after the field research, another $2^{\text {nd }}$ meeting at the school allowed for the presentation of the survey results to the respondents and a group discussion. The schematic appendix was an instruction and a map with marked route, dominants and frontages requiring assessment.

The respondents received instructions on exemplary assessments and symbols, and then entered information on the sensory assessment of public spaces in the table, which was attached to the main graphic study - valorization on the prepared map.

Through field research, observations and graphical assessment, it was determined how a given public space affects the senses, whether it is assessed positively or negatively, and how the visual assessment differs from that made by other senses. As part of the visual assessment in terms of the sense of sight, spatial order, aesthetics, dominants, architectural details, greenery, etc. were assessed. Here, the assessment was similar to the "Wejchert impression curve" [6] [7] however, the aspect of landscape elements on the left and right side of the evaluator was taken into account, but also those located in a different spatial relationship, e.g. above, below or behind it. The following elements of space have become important: balconies, tree crowns, authentic pavement, closings and perspective openings seen in a given place, visible church towers, or a panorama of the left bank of Warsaw.

Assessment by touch included a wide range of sensations, including: temperature, sun, shade, humidity, dry air, the type of wind on the face (open and closed areas), and even materials or textures, sculptures, walls, paving, pavement or greenery. While examining by touch, the participants gently or strongly pressed the surfaces, knocked, stroked, stomped, scratched, nudged, squeezed, leaned against the walls of tenement houses, and even hugged, for example, trees. The research revealed that sometimes people traverse a space and come into contact with other people or buildings. Sometimes, while waiting for someone, they lean against the walls of buildings. The following ratings appeared in the description: "grainy, rough, soft, smooth, muddy, fluffy, spiky, dirty, dry, wet, cold, warm, hard, slippery, moss-covered, wooden, steel, stone, brick, concrete, plastic, sticky, lumpy. "

By examining the sense of hearing, for example, the following sensations were determined: music from a restaurant, rustling leaves, pigeons, rattling of wheels on pavement, noise of construction sites, noise of streets, sound of a tram, train, church bells, chimes on the school tower, conversations of passers-by, their language, nationality, vocabulary, dialect, tone of voice, restaurant buzz, sounds of a performance event. The following sensations were defined in the sense of smell: the smell of chocolate, donuts, stew, dumplings, tripe, dried mushrooms, lord's crust, cookies, construction, dust, concrete, autumn leaves, earth, cobblestones, concrete, brick walls, decayed wood, pizza, stench gate and underground passages, exhaust gases, etc.

In addition, the perception of time was examined and here were defined: spaces in which the passage of time or the circadian cycle is clearly visible, or where time stops or ceases to matter. Clock towers, chimes, clocks on parking meters, open shop windows and restaurants, neon signs, street lamps, lighting, visible increased traffic or traffic jams, other characteristic events in public space that inform us about the passage of time, orientation towards the sides of the world turned out to be important, people's relationships in the space, rush or quiet conversations in restaurants, birds singing in the morning, dogs barking in the evening and more. In the study of the sense of proprioception - the feeling of balance, the sense of stability, information about high curbs (e.g. Floriańska Street), stairs (e.g. in front of the Warsaw-Praga Diocese Curia), unevenness, e.g. authentic pavement, barriers or thresholds were determined.

The taste test was the most difficult to describe. According to the theory, we also taste using the senses of smell and sight, we remember the flavors of food eaten in restaurants 
(goulash, pork chops) or on the street (dumplings, tripe, candyfloss). Where and how are the dishes served (street, restaurant, milk bar, oriental cuisine, Polish cuisine, exotic dishes, cafe, bar with alcohol only, etc.). Do people eat while standing up? Do they eat their meals comfortably at the tables? Is it elegant? What's the atmosphere like? Is it fast food? Do people enjoy the taste? Is it a to-go dish? Do we eat on a busy street, in the aisle? They can also be childhood memories or dishes prepared by residents and eaten in apartments along the route. As part of the study, there was no separate time for tasting, but the participants could consume their own tastes that fit into the multi-sensory landscape of the district. These include, for example, the famous and almost regional product "dumplings from the Różycki Bazaar" made in a traditional way and sold at the market stall.

In the next stage of hybrid research, the aggregation and interpretation of data on multisensory perception of places obtained as part of: questionnaires, multisensory valorization, interview and scientific walk were prepared. The results from the questionnaire were presented in the form of a graph (Fig. 8) presenting the indications in the examined points in the field for the three most important senses in a trial assessment: sight, hearing and smell. Whereas, graphic studies - multi-sensory valorization (Fig. 7) with detailed information constituted the background illustrating the decisions visible in the assessment. Information on the issues accompanying the multi-sensory perception of public spaces was provided by the coding of interviews (Table 1) and a science walk.

\section{Findings}

The graph (Fig. 8) with the assessment was prepared on the basis of questionnaires concerning the multisensory assessment of research points. It presents a clear discrepancy in the perception of some public spaces in terms of different senses. Places that were highly rated visually (no. 1- at Solidarności Avenue, Targowa St. - no. 5, Ząbkowska St. - no. 9) received an extremely low score in terms of the sense of hearing. You can also see that the visual assessment of space is much higher than that made in terms of other senses. In terms of smell, places where gastronomy is located and the aroma of meals is noticeable (square in front of the church and the Rusałka bar located there - no. 2, Ząbkowska Street no. 8 and 9 and Konesera Square - no. 9 and 10) were highly rated. This illustrates the validity of the above research and illustrates how much other senses affect the perception of space and the importance of non-visual stimuli for the attractiveness of the place. Although the following senses were examined: sight, touch, taste, smell, hearing, time perception and proprioception, in the case of Praga-Północ, the senses of sight, hearing and smell played a key role in the multi-sensory assessment. 


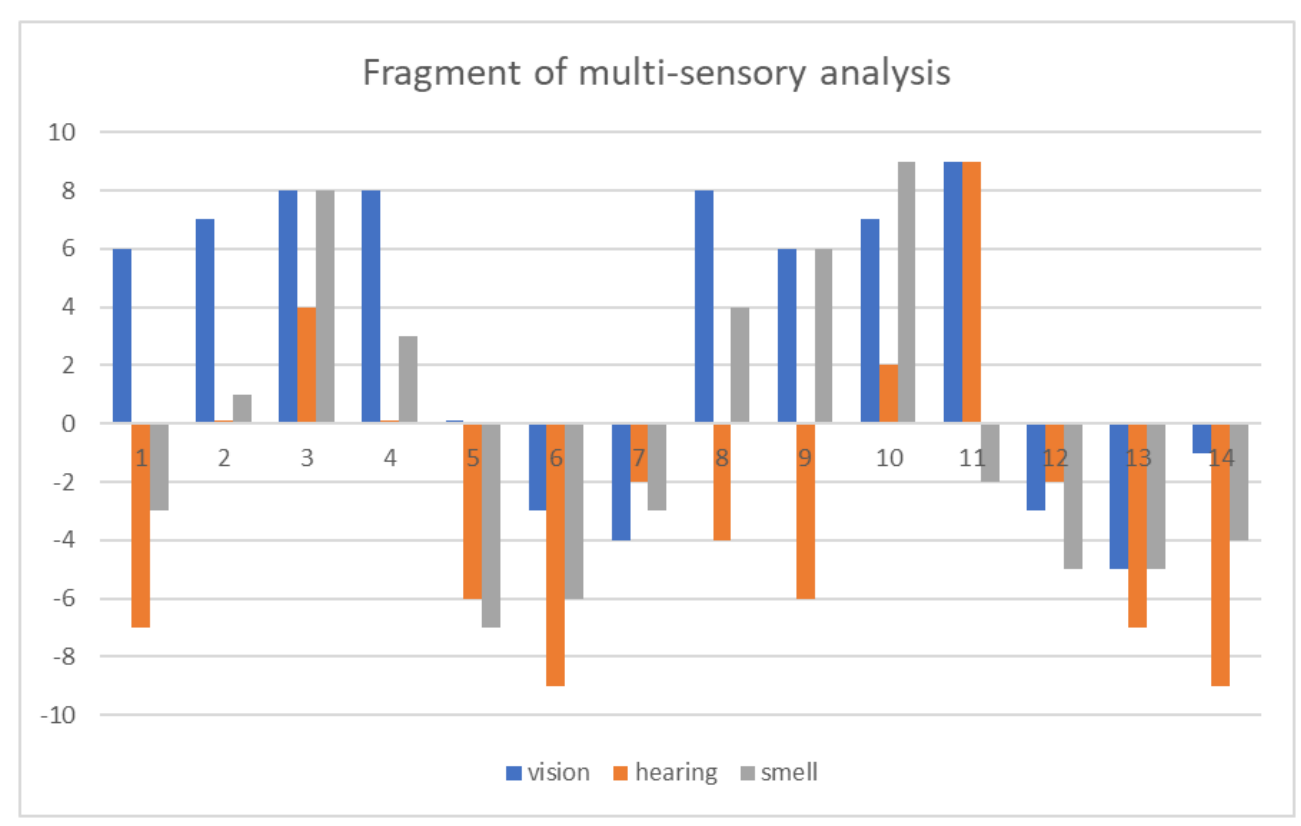

Fig. 8. Summary of evaluation graphs in terms of the three senses in relation to selected spaces. 1-14 public spaces - assessment points. The graph shows the sum of the points received by each of the individual places from all groups participating in the study

In the multi-sensory evaluation as well as the transcribed and interpreted interview, the respondents noted primarily: "unusual historical architecture", landscape elements: "nice view", "ivy on the wall", "nice greenery", "sunny street" details "ugly signboard", " a red brick that creates a mood, but also the "dying away" of public spaces: "decaying buildings" or "no people". In the landscape of Praga's - Północ scents, incl. the smells of the restaurant were noticed: "smells like hot-dog", "smells like black pudding", "smells like ketchup", "it stinks", but also "smells like rosebuds", "smells like vodka", "feels like there is construction sight nearby". Among the noises, the following were distinguished: heavy traffic, "renovation of a historic tenement house", "noise of cafe gardens", "rattling of wheels on pavement", "rustling of leaves", "nice music". Terms referring to all the senses appeared: "nice atmosphere", "cool place". The multi-sensory perception was fuller and richer in places where road traffic was excluded or limited (eg Koneser Square, Floriańska Street)

The multi-sensory valorizations of Praga-Północ, the questionnaires and interviews with the research groups are consistent on the basic issues concerning the core elements of the urban composition and the reactions caused by the strongest stimuli. The multitude of received stimuli and observations clearly depended on the sex of the respondents and their individual sensitivity. All those public spaces characterized by high spatial order, good technical condition of buildings, greenery and a diverse offer of social infrastructure, mainly trade and services, were positively assessed. (Floriańska Street, Koneser Square, Ząbkowska Street)

The following spaces were assessed negatively: with a lot of noise and traffic, urban tissue degradation, "socially dead", with visible phenomena of social pathology in the public space (intersection of Targowa and Ząbkowska streets with an underground passage, Bazar Różyckiego). The multi-sensory valorization of public spaces in Praga-Północ was similar 
in the assessment of all groups of respondents. However, in such a dynamically changing socio-economic area, the valorization should be repeated in subsequent groups of respondents, as this was only a sample group.

\section{Summary}

The multi-stage hybrid research procedure allows for a comprehensive multi-sensory evaluation of public spaces, covering many complex stages, including consultations with experts, functional and spatial analyzes, in situ research and other hierarchically related, although sometimes in a complex relationship. One of the final stages is work with previously selected respondents, taking various and parallel forms: questionnaire, multi-sensory valorization, interview and scientific walk. This is an important element related to social participation and the involvement of residents associated with the area in determining its potential, which in turn may translate into the stage of formulating design guidelines. The final stages of the hybrid research methodology concern the aggregation and interpretation of data on multisensory perception of places. The research procedure culminates conclusions and proposals in terms of the multi-sensory perception of public spaces in urban planning. Depending on the case, however, they influence the re-verification of their characteristics in terms of the diagnosis of problems related to public spaces, as demonstrated by trial studies.

New investments affect the "dying away" of other public spaces, and this in turn affects their perception by the observer in terms of many senses. The investment of Centrum Praskie Koneser, highly rated by the respondents, attracts visitors and residents. On the other hand, the neglect of many other public spaces, both technically and socio-economically, visible in the research results, contributes to low attractiveness and evaluation. The research in the trial area reflects the desolation of Ząbkowska St. much more negative among the surveyed observers was the impression of "dead spaces" than unsightly architecture. The attractive commercial offer of the CPK, neat, well-equipped and aesthetic spaces, and unique monuments made this place a clear success. During the year, this drastically affected the number of users and the structure of services and trade on Ząbkowska St. Activities of the local government to revive Ząbkowska St, among others the "Otwarta Ząbkowska" event, did not bring the expected results. The multi-sensory valorization of these spaces confirms above mentioned observations. The respondents referred to it as "nothing is happening", "lack of people" or "emptiness".

What could be competitive or otherwise supplementary to the space of the Praga Koneser Center, highly rated by the respondents, is authenticity related to multi-sensory perception. Building a community of residents through events such as former backyard meetings under the slogan "Neighbors to neighbors" and social participation with involvement in deciding about changes in the public space. Individual public spaces should be adapted so that both young and old residents of the immediate vicinity can comfortably spend their time there. Only such action in space will allow for its permanent revival, also outside organized events or the tourist season. Referring to A. Bańka [19] [20], in order to enliven places, one should not study history, but refer to the memory of events in places where life was vibrant. The influence on increasing the attractiveness of the space is the creation of sequences of connections between them - this is "kinostatic" memory - passages, promenades, piers or numerous pedestrian precincts illustrate the remembering of urban spaces through movement. However, due to the change in the social structure, cultural patterns, emotional attitudes and the concept of socially important places are also changing. The historical significance of places such as the Różycki Bazaar does not function in the minds of young people and immigrant communities. They 
have not experienced social interactions in this public space and evaluate it through the prism of the present. Thus, the value of the memory of the senses is also diminishing.

Quoting after A. Bańka "The acoustic space is compulsory - you cannot close your ears. Acoustic space control is important for the quality of life. "The trial study showed how important it is to limit car traffic, create a system of connections between individual public spaces and introduce greenery and ecological solutions in various forms: green walls and terraces, plant and architectural hybrids, pocket parks, community gardens, green tracks, flower meadows, street retention canals, or renewable energy sources. Sensual spatial diversity far from "bedroom districts" stimulates social behavior. In terms of multi-sensory aspects, the attractiveness of space can be increased, among others, by: smells and calm, moderately quiet music coming from the restaurant, introducing splash and noise of water, playing benches, sculptures, playground equipment and reducing heat islands through greenery. Then, you can obtain a sonic valorization of the space in which the rustling of leaves, children's laughter, barking dogs and singing birds in the morning reappear. Small architecture, and especially sculptural forms, have a different temperature and texture, which triggers different spheres of sensory perception. Additionally, it is important to keep the elements on a good "human" scale, avoid glaring contrasts, and introduce soft lighting and related colors. All this determines the harmony in multi-sensory perception.

In the light of these research processes, the concept of establishing a statutory form of protection of the area by creating a Cultural Park [46] in Warsaw's Praga - Północ district, aimed at preserving the heritage and increasing its attractiveness, seems to be correct. It will also be significant to use research on multi-sensory valorization in order to preserve these important stimuli that are part of the landscape of the district, which constitute the multi-sensory heritage: "rattle of wheels on authentic stone pavement", "church bells", "chimes on the tower", "market buzzing", " Praga band "," Wedel chocolate fragrance "and others. As part of the activities in the field of the Cultural Park, action on all senses should also be considered. Hence, to revive the degraded Różycki Bazaar. Introduce the Open Workshops of Craftsmen available on one tourist route and open workshops (ceramics, seamstress, umbrella maker, shoemaker, purse maker, furrier and others). This procedure, emphasizing the heritage of Praga related to craftsmanship, would at the same time have a positive impact on all senses to revive selected public spaces.

According to A. Hauziński [10] [11] "An optimal environment should provide stimuli of varying intensity, combine movement with activity, express the attitudes and values of the inhabitants. Such an environment is conducive to shaping local identity among groups of residents. "The optimal space perceived in many senses allows for efficient orientation in the environment, especially in a difficult situation related to the threat, when there is no support of navigation devices, signs or other people. This reduces the feeling of aesthetic chaos, stress and danger. The optimal sensory urban environment allows freedom of behavior and interpersonal interactions, as well as the regulation of the supply of stimulation. On the daily journey from home to school or work, an individual is exposed to an overload of information, of which only some of it reaches them. Others, unaware, act as stressors on the psyche (A. Bańka) [19] [20]. People also naturally strive to define their territory, which is difficult in an urban environment. Then, the solution is space therapy - access to places with moderate environmental stimulation, especially important for the elderly.

Comprehensive - hybrid research methodology allows for conducting research on multi-sensory perception of space and its recording based on, inter alia, qualitative research - multi-sensory valorization, but most of all it is preceded by an empirical method: literature 
on the subject was searched, collected and analyzed. Archival and present documents, plans, cartographic sources and satellite photos were studied. A rich photographic documentation was made, presenting the valorization of the space of places in the course of time, at different seasons, different times and circumstances. Research stages include, among others work with the social community, which means the proper selection of respondents (people who know the given spaces from their own experiences and interactions) and preparation of the group of respondents so that it is possible to later efficiently interpret the data and aggregate it A. Gendźwił [40]. This led to the description and interpretation of research in the area and sample group. Finally, conclusions related to the multi-sensory perception of space were formulated regarding the proposed improvement actions in the functional and spatial aspect. This illustrates the essence of the hybrid methodology of research into multi-sensory public spaces in urban planning.

Knowledge about multi-sensory experiences can help urban designers in shaping space in a way that reduces negative feelings, e.g. fear, and strengthens the positive ones - freedom and liberty. The hybrid methodology of research on the multi-sensory perception of public spaces allows for a full, more conscious and reliable assessment of the surrounding reality. The use of multi-sensory valorization of public spaces, questionnaires, interviews and walks, preceded by other studies, including analysis of literature and data, observation, discussion with representatives of the local community and experts, functional and spatial analysis as well as photographic inventory, allow for the creation of a multi-sensory image of selected places. The development of these activities will lead to the determination of: connecting the city's form with the structure of the needs and goals of its inhabitants, establishing the elements important for the multi-sensory character of the district and their significance in the local identity.

\section{Literature}

[1] Jałowiecki B. and Szczepański M.S., Miasto i przestrzeń w perspektywie socjologicznej. Warszawa: Wydawnictwo Naukowe Scholar, 2010.

[2] Aristotle, “O Duszy”, in Dzieła wszystkie, Warszawa: Wyd. Naukowe PWN, tome 3, 1992.

[3] J. Ekel, J. Jaroszyński, J. Ostaszewska. Mały Stownik Psychologiczny. Warszawa: Wiedza Powszechna, 1965, p. 180.

[4] Colman A.M., Stownik psychologii. Warszawa: Wydawnictwo Naukowe PWN, 2009.

[5] Lynch K. The image of the city. Cambridge: MIT press, vol. 11, 1960.

[6] Wejchert K., Elementy kompozycji urbanistycznej. Warszawa: Wydawnictwa Arkady, 1984.

[7] Wejchert K., Przestrzeń wokót nas, Katowice: Fibak Norma Press, 1993.

[8] Tomaszewski T., „Człowiek i otoczenie”, in Psychologia, Warszawa: PWN, 1975.

[9] Tomaszewski T., „Orientacja w otoczeniu”, in Psychologia, Warszawa: PWN, 1976.

[10] Hauziński A., "The evolution of the cognitive map in psychology. Discussion regarding the research of hierarchy plans and goals of activity”, Czasopismo Psychologiczne, vol. 16., no.2, 2010, pp. 275-288.

[11] Hauziński A., "Ewolucja pojęcia mapy poznawczej w psychologii i jej wykorzystanie w urbanistyce, architekturze oraz geografii", Zachowanie, Środowisko, Architektura, vol. 5, 2011, pp. 15-38,

[12] Golledge Reginald G. "Methods and methological issues in environment recognition research", in Environment Knowing: Theories, Research and Methods, Stroudsburg: Dowden, Hutchinson \& Ross, 1976, pp. 300-313, 
[13] Evans G.W., Pezdek K., "Cognitive mapping: Knowledge of real-world distance and location information", Journal of Experimental Psychology: Human Learning and Memory, vol. 6 , 1980, pp. 13-24.

[14] Evans G.W., "Environmental cognition”, Psychological Bulletin, vol. 88, 1980, pp. 259-287.

[15] Evans G.W., Marrero D.G., Butler P.A., "Environmental learning and cognitive mapping”. Environment and Behavior, vol. 13., no.1., 1981, pp. 83-104.

[16] Evans G.W., Skorpanich M. A. Garling T., Bryant K.J., Bresolin, B., "The effects of pathway configuration, landmarks and stress on environmental cognition", Journal of Environmental Psychology, vol. 4, 1984, pp.323-335.

[17] Foley J.E., Cohen A.J., "Working mental representations of the environment", Environment and Behavior, vol. 16, 1984, pp. 713-729.

[18] O'Keefe J., Nadel L., The Hippocampus as a Cognitive Map. New York: Clarendon, 1978.

[19] Bańka A., Architektura psychologicznej przestrzeni życia. Behawioralne podstawy projektowania. Poznań: Gemini S.C., 1997.

[20] Bańka A., Społeczna psychologia środowiskowa. Warszawa: Wydawnictwo Naukowe "Scholar", 2002.

[21] Bell P. A. et al., Psychologia środowiskowa. Gdańsk: GWP, 2004.

[22] Jałowiecki B., "Percepcja przestrzeni Warszawy", Studia Regionalne i Lokalne, vol. 2(2), 2000, pp. 79-100.

[23] Szkurłat E., "Psychologiczne i kulturowe uwarunkowania percepcji środowiska", in Percepcja współczesnej przestrzeni miejskiej, Warszawa: Wydział Geografii i Studiów Regionalnych Uniwersytetu Warszawskiego, 2007, pp. 63-72.

[24] Rybicka, E., "Poza pisanie/czytanie miasta”, Teksty Drugie, vol. 3, 2007, pp. 107-112.

[25] Rewers E., "Post-polis: wstęp do filozofii ponowoczesnego miasta”, Kraków: Universitas, vol. 41, 2005.

[26] Kietlińska B., "Jak za pomocą metod jakościowych zbadać zmysłowy odbiór miasta?”, Nauka i Szkolnictwo Wyższe, vol.1(41), 2013, pp.131-142.

[27] Simmel G., "Socjologia zmysłów”, in: Most i drzwi. Wybór esejów. 2006, pp.184-203.

[28] Pink S., “Doing visual ethnography”. London: SAGE Publications, Ltd., 2007.

[29] Bartnicka M., "Wyobrażenia przestrzeni miejskiej Warszawy (Studium geografii percepcji)”, Dokumentacja Geograficzna, vol. 2, 1989.

[30] Libura H., “Aspekty kartograficzne map wyobrażeniowych”, Polski Przegląd Kartograficzny, vol. 15(3), 1983, pp. 126-131.

[31] Mordwa S., Wyobrażenia przestrzeni miast Polski Środkowej. Na podstawie badań grupy młodzieży licealnej. Łódź: Wydawnictwo Uniwersytetu Łódzkiego, 2003.

[32] Daniel T.C., Boster R.S., "Measuring Landscape Esthetics: The Scenic Beauty Estimation Method", in: Proc. Our National Landscape: A Conference on Applied Techniques for Analysis and Management of the Visual Resource - 1976, USDA Forest Service Research Paper, Department of Agriculture, Forest Service, Rocky Mountain Forest and Range Experiment Station, vol. 167, pp. 514-523.

[33] Okołowicz M.A., Kowalska J.M., “Jakiej przyrody chcemy w miastach? Pomiar estetyki krajobrazu nad Wisłą w Warszawie metodą Scenic Beauty Estimation", Przestrzeń i Forma, vol.26, 2016, pp. 243-256. https://doi.org/10.21005/pif.2016.26.D-07

[34] Kitchin R., "Cognitive maps: what are they and why study them?", Journal of Environmental Psychology, vol. 14, 1994, pp. 1-19.

[35] Kitchin R., "Methodological convergence in cognitive mapping research: Investigating configurational knowledge", Journal of Environmental Psychology, vol. 16, 1996, pp. 163-185. 
[36] Kitchin R., Blades M., The cognition of geographic space. London, New York: L. B. Tauris Publishers, 2002.

[37] Castellar S.M.V., Juliasz P.C.S., "Mental map and spatial thinking", in Proceedings of the ICA 1, vol. 1, 2018. https://doi.org/10.5194/ica-proc-1-18-2018

[38] Waterman S., Gordon D., "A quantitative-comparative approach to analysis of distortionin mental maps”, Professional Geographer, vol. 36(3), 1984, pp. 326-337.

[39] Gould P., On mental maps. University of Michigan: Ann Arbor, 1966.

[40] Gendźwiłł A., “O prezentacji kartograficznej wyników badań map poznawczych”, Polski Przegląd Kartograficzny, vol. 41(2), 2009, pp.115-127.

[41] Foland, A., "Psychokartografia-metoda badania przestrzeni miejskiej”, in: Dynamika przestrzeni miejskiej, Poznań: Wydawnictwo Poznańskie, pp. 107-119, 2006.

[42] Lewicka M., "Ewaluatywna mapa Warszawy: Warszawa na tle innych miast", in: Społeczna mapa Warszawy. Interdyscyplinarne studium metropolii warszawskiej, Warszawa: Scholar, 2004, pp. 316-336.

[43] Iwańczak B., "Metody badawcze całościowej percepcji przestrzeni miasta na przykladzie Warszawy", Kwartalnik Architektury i Urbanistyki, vol. 62, 2017, pp. 69-85.

[44] Nieścioruk K., "Kartograficzny obraz map mentalnych przestrzeni miejskiej i jego prezentacja oraz analiza z zastosowaniem narzędzi systemów informacji geograficznej”, Acta Scientiarum Polonorum. Geodesia et Descriptio Terrarum, vol. 12(4), 2013, pp. 27-40.

[45] Nieścioruk K., "The use of mental and sketch maps as a tool to evaluate cartography teaching effectiveness", The Cartographic Journal, vol. 53(2), (2016), pp. 186-196. https://doi.org/10.10 80/00087041.2015.1108064

[46] Czepkiewicz M., Jankowski P., Zwoliński Z., "Geo-questionnaire: a spatially explicit method for eliciting public preferences, behavioural patterns, and local knowledge-an overview". Quaestiones Geographicae, vol. 37(3), 2018, pp. 177-190. http://doi.org/10.2478/quageo-2018-0033

[47] Haklay M., Jankowski P., Zwoliński Z., "Selected modern methods and tools for public participation in urban planning-a review", Quaestiones Geographicae, 37(3), 2018, pp. 127-149. https://doi. org/10.2478/quageo-2018-0030

[48] Czepkiewicz, M. et al., "Public Participation GIS for sustainable urban mobility planning: methods, applications and challenges", Rozwój Regionalny i Polityka Regionalna, vol. 35, 2016, pp. 9-35.

[49] Biegański L., Buczek G., Gzell S., Kowalewski A., Markowski T., Cichy-Pazder E., "Karta Przestrzeni Publicznej”, in III Kongres Urbanistyki Polskiej ZMP i TUP, Poznań 2009.

[50] Ustawa z dnia 27 marca 2003 r. o planowaniu i zagospodarowaniu przestrzennym, Warszawa: Rada Ministrów, DzU 2003, Nr 80, poz. 717 z późn. zm.

[51] Jarecka - Bidzińska E., "Praga-Pótnoc w Warszawie jako ,dzielnica sztuki” na tle wybranych przykładów z metropolii Europy i Ameryki Pótnocnej”. Ph.D. desideration, Warsaw University of Technology, Warsaw 2018.

[52] Osowski J., "Ile osób jeździ druga liniq metra? Mamy szczegółowe dane. Stacja Wileński oblegana, a Powiśle... ", Gazeta Wyborcza, 20 March 2015. Available: https://warszawa.wyborcza.pl/ warszawa/7,34862,17627910,ile-osob-jezdzi-druga-linia-metra-mamy-szczegolowe-dane-stacja. html [Access: 01 Jun 2021] 